ENSAYO

\title{
LA INCULTURACIÓN DEL EVANGELIO, UN DESAFÍO CRUCIAL DE LA IGLESIA CATÓLICA
}

\author{
Sergio Silva G., ss.cc.
}

Los creyentes de cualquier religión viven su fe "inculturada”, es decir, de acuerdo a los valores, ideas y sistemas de expresión y de acción de su propia cultura. Lo mismo ocurre con la fe cristiana. Un problema surge cuando se intenta llevar el Evangelio de Jesús a pueblos de culturas diferentes de la de los evangelizadores. El problema ya se presentó en la época del Nuevo Testamento, cuando Bernabé y Pablo empezaron a misionar a los no judíos. Volvió a presentarse cuando, a partir del Renacimiento, se fue gestando en la Europa ya cristianizada la cultura moderna. Aunque el Concilio Vaticano II (1962-1965) dio los primeros pasos de apertura de la Iglesia católica hacia el mundo moderno, ésta —se advierte en este ensayo- está lejos de haber logrado resolver el problema de la

Sergio Silva Gatica, ss.cc. Doctorado en Teología, Universidad de Ratisbona, Alemania, y estudios en filosofía e ingeniería civil. Profesor titular y director del Magíster en Teología Fundamental, Universidad Católica de Chile. Autor de La Idea de la Técnica Moderna en el Magisterio de la Iglesia, desde Pío XII hasta Juan Pablo II (con la colaboración de Pedro Boccardo, Pontificia Universidad Católica de Chile, 1989), Teología de la Creación (Seminario Pontificio Mayor de los Santos Ángeles Custodios, 1992, $3^{\text {a }}$ edición), ¿Por Qué Murió Jesús? Iniciación a los Evangelios (Ediciones Universidad Católica de Chile, 1996), entre varios otros libros y artículos en compilaciones y publicaciones periódicas.

Estudios Públicos, 101 (verano 2006). 
inculturación de la fe en la modernidad. Para avanzar, se requiere que haya en ella un laicado adulto en su fe y que toda la Iglesia tenga una actitud de empatía ante la modernidad. A juicio del autor, un punto neurálgico en este proceso lo constituye el fenómeno, cada vez más decisivo, de la tecnociencia.

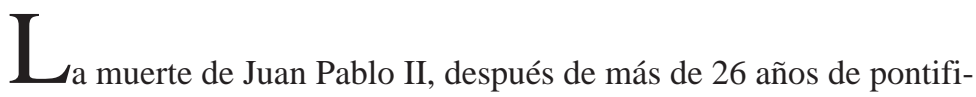
cado, invita a una doble mirada: una retrospectiva, para hacer un balance de su gobierno; la otra, prospectiva, para analizar los desafíos que enfrenta la Iglesia católica en el presente y en el futuro próximo. Elijo esta segunda y me concentro en el desafío de la inculturación del Evangelio. Luego de exponer en qué consiste este desafío (1.), presentaré lo que me parece que es la tentación de la Iglesia actual ante él (2.) y dos condiciones de posibilidad para que sea efectivamente enfrentado (3. y 4.); terminaré proponiendo un aspecto de la inculturación del evangelio en el mundo de hoy, poco tenido en cuenta hasta ahora (5.).

\section{La inculturación del Evangelio}

a) En los evangelios se describe cómo Jesús de Nazaret, en los años del emperador romano Tiberio, proclamó en Palestina la cercanía inminente del Reinado de Dios. Jesús se refería explícitamente a la esperanza de su pueblo, expresada y sostenida por los profetas. Esta esperanza consistía en que en algún momento de la historia de Israel tendría lugar una nueva intervención del poder bondadoso de Yavé, el Dios de Israel, destinada a establecer definitivamente la paz y la justicia. Y no sólo para beneficio de Israel, sino para toda la humanidad; incluso más, esta intervención afectaría también al cosmos todo.

Por eso, Jesús podía anunciar la cercanía del Reinado de Dios como una buena noticia ${ }^{1}$. Dice el evangelista Marcos: "Después que Juan² fue tomado preso, marchó Jesús a Galilea; y proclamaba la buena noticia de Dios: 'El tiempo se ha cumplido y el Reinado de Dios se ha acercado; conviértanse y crean en la buena noticia”” (Mc 1,14-15). La esperanza en

\footnotetext{
${ }^{1}$ En griego, buena noticia se dice “euanguélion”, palabra que fue transcrita al latín y de ahí al castellano como "evangelio".

${ }^{2}$ Se trata de Juan Bautista, precursor de Jesús.
} 
esta acción definitiva de Dios en la historia humana —una intervención "escatológica”, dice la teología— atraviesa todo el Antiguo Testamento ${ }^{4}$.

Tanto el Antiguo Testamento como Jesús y los evangelios se expresan de acuerdo a la cultura de su respectiva época. A pesar de que los escritos del Antiguo Testamento provienen en su mayoría del siglo VI a.C. - aunque recogen tradiciones transmitidas oralmente durante varios siglos-, el cambio cultural es tan lento e imperceptible que en la época de Jesús no se tienen problemas de fondo para comprender los escritos de los profetas ni del Antiguo Testamento en general.

b) El problema de la inculturación se plantea por primera vez para la comunidad apostólica recién hacia el año 40 d.C., cuando se convierten a la fe en Jesús los primeros grupos de no judíos, de cultura griega (o helénica). Hasta ese momento los cristianos eran todos judíos y vivían su fe en Jesús en continuidad con su cultura. Al incorporarse a la comunidad los primeros no judíos surgió la pregunta de si ellos debían vivir la fe cristiana igual que los cristianos de origen judío. El único precedente disponible era el de los “prosélitos” judíos, gente de origen no judío que se convertía a la religión de Israel, y tenían que hacer suya, junto con la Ley de Moisés, la cultura judía.

La comunidad apostólica era heredera de Israel, también en este punto. El descubrimiento de la posibilidad de vivir el evangelio de Jesús y la fe en él en otra cultura fue obra de un grupo algo marginal de la comunidad apostólica, reunido en torno a Pablo (o Saulo) de Tarso. Pablo no había conocido a Jesús; es más, había perseguido tenazmente a los cristianos. Pero una experiencia misteriosa, a las puertas de Damasco — ciudad a la que se dirigía para apresar a los cristianos que encontrara en ella— ${ }^{5}$, lo convirtió no sólo en discípulo de Jesús sino en el principal enviado a convertir a los "gentiles"6. Pablo había hecho en su propia persona una experiencia cultural sorprendente: se había criado en dos culturas a la vez, la judía de sus padres y de su fe, y la griega de su ciudad natal. Podía ver, por lo tanto, cosas que se escapaban a los cristianos de origen judío; por ejemplo, que los valores de la fe bíblica no están ligados necesariamente a la cultura

\footnotetext{
3 "Escatológico" es la trascripción de una palabra griega compuesta de "ésjaton” (que significa último, final, y por ello definitivo) y "logos” (discurso racional).

${ }^{4}$ Por ejemplo, Isaías 11,1-9; 61,1-6.

${ }^{5}$ Hechos 9,1-20.

${ }^{6}$ En latín, "gentil" deriva de "gens" (de donde viene también el castellano "gente”), que significa familia, pueblo, raza. Se usa en la Biblia para designar a los no judíos, llamados por el Antiguo Testamento "los pueblos".
} 
judía, que pueden ser vividos también — necesariamente de otra manera— en la cultura helénica.

El Nuevo Testamento nos ha conservado algunas de las piezas de la polémica que se suscitó en la comunidad apostólica cuando estas comunidades de cristianos no judíos, animados por el grupo en torno a Pablo, empezaron a dejar de lado la cultura judía, incluidas gran parte de las prescripciones de la Ley de Moisés. Vale la pena recoger su enseñanza.

Pablo ${ }^{7}$ cuenta el problema que vivió en Antioquía con Pedro, cuando éste empezó a apartarse de la mesa de los cristianos griegos, para evitar hasta el contacto físico con ellos, porque eran considerados "impuros" por los judíos. Pablo le reprocha un doble error: por un lado, hace un acto de simulación, pues de hecho él ya no vive como judío; por otro lado, y más a fondo, no actúa según la verdad del Evangelio, que consiste en que la justificación es por la fe, no por las obras de la Ley. La fe es una relación personal con Dios por medio de Jesús, que se puede dar en cualquier cultura; no es necesario situarse primero en una determinada cultura - en este caso, la de las obras de la Ley, la cultura del judaísmo — para, desde ahí, poder recién encontrarse con Dios.

Lucas $^{8}$ también relata este episodio: "Bajaron algunos de Judea que enseñaban a los hermanos: 'Si no se circuncidan conforme a la costumbre mosaica, no pueden salvarse'. Se produjo con esto una agitación y una discusión no pequeña de Pablo y Bernabé contra ellos; y decidieron que Pablo y Bernabé y algunos más de ellos subieran a Jerusalén, adonde los apóstoles y presbíteros, para tratar esta cuestión” (Hech 15,1-2). Ya en Jerusalén, de nuevo se plantea el problema: "algunos de la secta de los fariseos, que habían abrazado la fe, se levantaron para decir que era necesario circuncidar a los gentiles y mandarles guardar la Ley de Moisés” (Hech 15,5). La comunidad apostólica se reúne a tomar una decisión. El relato da cuenta de dos discursos, uno de Pedro, el otro de Santiago. Los argumentos son los tres siguientes: 1) Dios ha actuado con los no judíos que han creído, igual que con los judíos; en palabras de Pedro: "Dios, conocedor de los corazones, dio testimonio en su favor comunicándoles el Espíritu Santo como a nosotros; y no hizo distinción alguna entre ellos y nosotros, pues purificó sus corazones con la fe" (Hech 15,8-9). Santiago muestra que esto estaba ya anunciado por los profetas. El argumento se refuerza cuando Pablo y Bernabé cuentan "todos los signos y prodigios que Dios había realizado por medio de ellos entre los gentiles” (Hech 15,12). Los que ejercen la auto-

\footnotetext{
${ }^{7}$ Gálatas 1-2.

${ }^{8}$ Hechos 15.
} 
ridad en la Iglesia reconocen que su autoridad está al servicio de la acción de Dios, siempre bajo ella. 2) A esto se añade que Pedro reconoce que la Ley es un yugo insoportable. Dirigiéndose a los judaizantes, les dice: “¿Por qué, pues, ahora tientan ustedes a Dios imponiendo sobre el cuello de los discípulos un yugo que ni nuestros padres ni nosotros pudimos sobrellevar?” (Hech 15,10). Este argumento reconoce la fragilidad humana, la limitación; no se ilusiona con falsas omnipotencias. 3) Finalmente, la salvación es por gracia, lo que vale tanto para los judíos como para los no judíos. En palabras de Pedro: "Nosotros creemos más bien que nos salvamos por la gracia del Señor Jesús, del mismo modo que ellos” (Hech 15,11). Se repite el argumento de una fe que es de raíz personal, por lo que es libre frente a la diversidad cultural.

El episodio de los judaizantes permitió a la Iglesia apostólica comprender que el Evangelio que ella vive y comunica no está atado a una determinada cultura. Aquí se descubre un aspecto importante de la libertad cristiana, que en esto supera al judaísmo. La libertad no consiste en que se pueda vivir un Evangelio en cierto sentido puro, no inculturado en una determinada cultura; el ser humano que vive el Evangelio es inseparable de su cultura. La libertad consiste en que la autocomunicación de Dios — contenido y realidad central del Evangelio - la puede recibir y vivir cualquier ser humano en su propia cultura; no es requisito previo a esta recepción el hacerse de otra cultura.

En este descubrimiento Pablo jugó un papel decisivo, precisamente gracias a su personal experiencia de pertenecer simultáneamente a dos culturas; Pablo — podemos decir- era "bilingüe cultural" por el hecho de haberse criado a la vez en la cultura griega de su Tarso natal y en la cultura judía de la comunidad a la que pertenecía su familia. Así, estaba preparado para percibir en carne propia la libertad cultural del cristianismo.

Hay que tener presente, sin embargo, que toda persona y comunidad recibe el Evangelio y la propuesta de la fe cristiana inevitablemente ya inculturada, al menos en dos culturas: la(s) de la Escritura y la de los evangelizadores. Éstos no sólo deben permitir — como una concesión- que los evangelizados inculturen el Evangelio en su propia cultura, sino que tienen que colaborar activamente con ellos en ese proceso, en el que se juega, como vio Pablo, la verdad del Evangelio.

c) Durante muchos siglos la Iglesia católica de Occidente pudo vivir la fe cristiana en la forma inculturada que se logró durante la Edad Media en Europa. De una manera más bien inconsciente, se suponía que ésa era la 
forma adecuada de vivir el Evangelio, por lo que se presionaba a los pueblos no europeos a convertirse a la fe así inculturada, dejándoles algunos espacios donde podían expresarse en su propia cultura, habitualmente los espacios de la religiosidad popular, no sometida a las normas oficiales y en cierta tensión con ellas. Fue esto lo que sucedió en la evangelización de América, que acompañó al proceso de conquista y colonización del continente, realizado por los imperios español y portugués. Fue también lo que sucedió en el siglo XIX con la inmensa oleada evangelizadora de África, Asia y Oceanía.

En el Concilio Vaticano II (1962-1965), la Iglesia católica tomó una conciencia nueva de la pluralidad de culturas que existen en la humanidad y del derecho de todo grupo humano a recibir el Evangelio en su propia cultura, sin tener que hacerse, previa o concomitantemente, de otra cultura. En 1974 un Sínodo de Obispos de todo el mundo reunido en Roma trató el tema de la evangelización. A fines de 1975 Pablo VI publicó la exhortación apostólica ${ }^{9}$ Evangelii Nuntiandi, donde recoge los trabajos de ese Sínodo y los asume con su autoridad papal. En ella afirma lo que se puede reconocer como la "Carta Magna” de la idea de evangelización de la cultura:

Lo que importa es evangelizar — no de una manera decorativa, como con un barniz superficial, sino de manera vital, en profundidad y hasta sus mismas raíces - la cultura y las culturas del hombre en el sentido rico y amplio que tienen sus términos en la Gaudium et Spes ${ }^{10}$, tomando siempre como punto de partida la persona y teniendo siempre presentes las relaciones de las personas entre sí y con Dios.

El Evangelio y, por consiguiente, la evangelización, no se identifican ciertamente con la cultura y son independientes con respecto a todas las culturas.

Sin embargo, el reino que anuncia el Evangelio es vivido por hombres profundamente vinculados a una cultura y la construcción del reino no puede dejar de servirse de ciertos elementos de la cultura y de las culturas humanas. Independientes con respecto a las culturas, Evangelio y evangelización no son necesariamente incompatibles con ellas, sino capaces de impregnarlas a todas sin someterse a ninguna.

La ruptura entre Evangelio y cultura es sin duda alguna el drama de nuestro tiempo, como lo fue también en otras épo-

${ }^{9}$ Una "exhortación apostólica” es un documento en que el Papa compromete su autoridad en un grado menor que cuando escribe una "encíclica".

${ }^{10}$ Se conoce con este nombre, por sus primeras palabras en el texto latino, la Constitución Pastoral sobre la Iglesia en el mundo de hoy del Concilio Vaticano II. 
cas. De ahí que hay que hacer todos los esfuerzos con vistas a una generosa evangelización de la cultura, o más exactamente de las culturas. Éstas deben ser regeneradas por el encuentro con la Buena Nueva. Pero este encuentro no se llevará a cabo si la Buena Nueva no es proclamada (EN 20).

d) Hoy vemos con claridad que la inculturación del Evangelio se hace necesaria no sólo cuando se trata de llevar la Buena Nueva de la fe a un pueblo que hasta ahora no la ha conocido, sino también cuando, en un pueblo que ya ha recibido y acogido en alguna medida el Evangelio, se produce un período de cambio cultural intenso y rápido. Es a mi entender la situación actual de Chile (y, más en general, de todos los países del hemisferio sur), sometido a la presión del llamado proceso de globalización, que no parece ser otra cosa que la difusión al mundo entero de la cultura moderna, propia de los países “desarrollados” del hemisferio norte, una cultura de fuerte impronta científico-técnica.

\section{La tentación de la Iglesia}

a) Ante esta nueva ola modernizadora, la tentación de los hombres de iglesia —el clero y los obispos, principalmente- me parece que es no querer ver que el cambio cultural en curso exige de la Iglesia un cambio correspondiente.

Por supuesto, no se trata de una mera adaptación condescendiente, como la que tienen que hacer las empresas cuando cambian los gustos de sus clientes. Por ejemplo, no se trata de legalizar el aborto, el divorcio y el matrimonio de homosexuales, como si fueran un bien, una nueva conquista de la libertad. Se trata de otra cosa más honda y más difícil: de hacer llegar el Evangelio a la gente tal como es, sin obligarla a salir de su cultura como condición previa para acoger y vivir el Evangelio. Ese Evangelio, acogido desde la propia realidad, tendrá que convertir no sólo a las personas individuales, sino también su cultura, en lo que tenga de no evangélico. Pero ese cambio lo harán los que se conviertan, desde dentro de su cultura y mediante los mecanismos de cambio de su cultura. No será una imposición desde fuera. Esto supone de parte de los evangelizadores, que siempre viven el Evangelio inculturado en su propia cultura, un desprendimiento no fácil de lograr, pues tienen que dejar a los evangelizados en libertad para crear su propia forma de vivir la fe.

Cuando los hombres de Iglesia caen en la tentación de no aceptar este cambio, suelen denunciar como males muchos de los rasgos propios de 
la cultura en cuestión. Es lo que parece estar sucediendo hoy con tantos "ismos" que se condenan en la cultura moderna en su fase actual: consumismo, hedonismo, relativismo, etc.

b) La Iglesia católica no está bien aperada para defenderse de esta tentación ante la cultura moderna. Desde los albores de los Tiempos Modernos se puso en contra de los cambios que empezaban a producirse. En su interior, luchó frontalmente con el protestantismo y su intento de reformar radicalmente la Iglesia. En el frente exterior, se puso en contra de los primeros grandes descubrimientos de las nacientes ciencias modernas -el "caso Galileo" es emblemático, pero no es el único- y en contra de los movimientos políticos emancipatorios: condenó la Revolución Francesa y su declaración de los Derechos humanos, se opuso tenazmente a la democracia como forma de gobierno, opuso la autoridad dogmática de la revelación a los esfuerzos ilustrados de usar libremente la razón. La difícil relación de la jerarquía de la Iglesia católica con la cultura moderna culmina durante el pontificado de Pío IX (1846-1878). A fines de 1864, el Papa publica la encíclica Quanta Cura. Como anexo a ella se publica el llamado Syllabus ${ }^{11}$ de los errores modernos. Se trata de una colección de 80 proposiciones modernas que el Papa ha ido condenando en diversos escritos durante sus ya casi 20 años de gobierno. El "Syllabus" termina con la proposición 80, que condena la siguiente afirmación: "El Romano Pontífice puede y debe reconciliarse y transigir con el progreso, con el liberalismo y con la civilización moderna”.

Una consecuencia de esta actitud de la Iglesia católica ante la modernidad fue su defensa de la herencia recibida, el "depósito de la fe". A medida que la modernidad — con buenas razones, a veces; otras, con no tan buenas - iba cuestionando diversos aspectos de esta herencia, las autoridades católicas reaccionaron de manera defensiva, aferrándose al carácter intocable de la tradición. Se fue gestando así un sistema eclesiástico que abarcaba todos los ámbitos de la vida cristiana: las doctrinas de la fe, las normas de la moral, las rúbricas de las celebraciones litúrgicas (el culto), las recomendaciones para el cultivo de la vida espiritual (las devociones), los reglamentos de la disciplina interna de la Iglesia. Con una evidente falta de perspectiva histórica, se tendía a pensar que este sistema, en todas sus partes, lo había heredado la Iglesia de la comunidad apostólica; quedaba así impregnado del valor propio de lo apostólico, vinculado a la revelación definitiva en Jesús. La tarea de la Iglesia debía ser, por lo tanto, transmitir

${ }^{11}$ En latín, “syllabus” (sílabo en castellano) significa lista, índice o catálogo. 
fielmente este sistema, sin cambios. El clero era concebido como el administrador del sistema, y era formado para ello. La conversión a la fe cristiana católica equivalía a salir de la propia cultura para integrarse a este sistema eclesiástico. Por una mal entendida fidelidad a la herencia recibida de Jesús, la Iglesia católica se centró en sí misma, concretamente en el sistema eclesiástico que he descrito. Y perdió la capacidad para percibir al otro en su diferencia, perdió capacidad de empatía.

c) En el Concilio Vaticano II la Iglesia católica ha iniciado un cambio de actitud ante la modernidad. Es sintomático de este cambio el título de la Constitución Pastoral Gaudium et Spes (GS), la que se aboca precisamente a la relación de la Iglesia católica con el mundo: es sobre "la Iglesia en el mundo actual”, ya no ante o frente a él, como si ella estuviese fuera del mundo. Esta Constitución se abre con las siguientes palabras, que expresan claramente la nueva actitud que se busca: "los gozos y las esperanzas, las tristezas y las angustias de los hombres de nuestro tiempo, sobre todo de los pobres y de cuantos sufren, son a la vez gozos y esperanzas, tristezas y angustias de los discípulos de Cristo. Nada hay verdaderamente humano que no encuentre eco en su corazón” (GS 1). Este párrafo inicial de Gaudium et Spes termina con la siguiente afirmación: "La Iglesia se siente íntima y realmente solidaria del género humano y de su historia” (GS 1). Ya no se trata de la actitud defensiva y autocentrada, sino que la Iglesia se abre empáticamente al mundo.

$\mathrm{Al}$ reconocerse plenamente insertada en el mundo actual, la Iglesia descubre también que se encuentra en un intercambio con el mundo moderno que la enriquece. "La Iglesia católica (...) tiene (...) la firme persuasión de que el mundo, a través de las personas individuales y de toda la sociedad humana, con sus cualidades y actividades, puede ayudarle mucho y de múltiples maneras en la preparación del Evangelio. Expónense a continuación algunos principios generales para promover acertadamente este mutuo intercambio y esta mutua ayuda en todo aquello que en cierta medida es común a la Iglesia y al mundo" (GS 40, al final; los subrayados son míos). Luego vienen tres párrafos en que se detalla "la ayuda que la Iglesia procura prestar" a cada ser humano (GS 41), a la sociedad humana (GS 42) y al dinamismo humano (GS 43). Finalmente, un párrafo en que se reconoce "la ayuda que la Iglesia recibe del mundo moderno" (GS 44). Ahí se hace la afirmación fundamental: "la Iglesia reconoce los muchos beneficios que ha recibido de la evolución histórica del género humano". El párrafo detalla dos niveles de estos beneficios. El primero es cultural: "La experiencia del 
pasado, el progreso científico, los tesoros escondidos en las diversas culturas, permiten conocer más a fondo la naturaleza humana, abren nuevos caminos para la verdad y aprovechan también a la Iglesia”. La razón es que la Iglesia, "desde el comienzo de su historia, aprendió a expresar el mensaje cristiano con los conceptos y en la lengua de cada pueblo y procuró ilustrarlo además con el saber filosófico. Procedió así a fin de adaptar el Evangelio al nivel del saber popular y a las exigencias de los sabios en cuanto era posible". Lo que fue en el pasado tiene que seguir siendo realidad hoy; por eso el texto saca la conclusión general: "Esta adaptación de la predicación de la palabra revelada debe mantenerse como ley de toda la evangelización". La justificación es "porque así en todos los pueblos se hace posible expresar el mensaje cristiano de modo apropiado a cada uno de ellos y al mismo tiempo se fomenta un vivo intercambio entre la Iglesia y las diversas culturas". Aunque Gaudium et Spes no usa el término "inculturación”, se está refiriendo aquí a la realidad a la que el término remite.

El segundo nivel de los beneficios que la Iglesia sabe que recibe del mundo es social. "La Iglesia, por disponer de una estructura social visible, señal de su unidad en Cristo, puede enriquecerse, y de hecho se enriquece también, con la evolución de la vida social”. Poco más adelante añade: “La Iglesia reconoce agradecida que tanto en el conjunto de su comunidad como en cada uno de sus hijos recibe ayuda variada de parte de los hombres de toda clase o condición". Y detalla los diversos lugares donde se ejerce esta ayuda: "el orden de la familia, de la cultura, de la vida económico-social, de la vida política, así nacional como internacional”. El párrafo termina con esta fuerte declaración: "Más aun, la Iglesia confiesa que le han sido de mucho provecho y le pueden ser todavía la oposición y aun la persecución de sus contrarios”.

Pero no basta con el reconocimiento verbal. Esta nueva actitud de la Iglesia ante la cultura moderna debe hacerse realidad en la vida cotidiana de los cristianos y de los hombres de Iglesia. Lo que supone una serie de cambios internos que la hagan posible. Sólo así podrá la Iglesia enfrentar el desafío de inculturar el Evangelio en el mundo de hoy tal como de hecho es. Voy a referirme a dos condiciones que me parecen prioritarias y decisivas. Una tiene que ver con la trama de la vida interna de la Iglesia — que la Iglesia sea verdaderamente de laicos, que éstos no sean en ella ni niños ni meros clientes-; la otra, con la actitud de la Iglesia — clero y laicadoante el mundo, una actitud que debe estar presidida por la empatía, en la línea abierta por la Gaudium et Spes. 


\section{Una condición interna de la Iglesia: Laicado adulto en la fe}

a) Si le preguntamos a un no católico qué entiende por "iglesia", probablemente nos va a responder que es un edificio, el "templo"; si lo urgimos un poco, podrá responder que "iglesia" son los obispos y los curas. Ambas respuestas posibles apuntan a algo real: lo más visible de la Iglesia católica son, por un lado, sus templos y, por otro, sus "funcionarios”, que son los que suelen aparecer en los medios de comunicación social hablando en nombre de la Iglesia.

El problema es que si les preguntáramos a los católicos, muchos de ellos nos darían la misma respuesta. Pocos nos responderían que la iglesia somos nosotros. Y esto es preocupante, porque significa que su relación con la comunidad eclesial es como la de un cliente con la empresa que le presta servicios.

La "culpa" — si se puede hablar así- de esta situación no la podemos cargar toda al laico católico. Es el resultado de una larga evolución, que hunde sus raíces en las querellas medievales entre los señores feudales europeos y los respectivos obispos; querellas llevadas al extremo cuando se enfrentaban el Emperador y el Papa. Normalmente se trataba de pugnas de poder; pero en ellas la parte eclesiástica no siempre logró discernir lo que estaba realmente en juego y muchas veces arremetió contra la parte laica desde su autoridad sacral. Los laicos podían aparecer así en rebelión contra sus autoridades religiosas.

Un nuevo aporte a este desgraciado malentendido vino de la época de la reforma protestante. Su principio del libre examen — basado en que los creyentes tienen la "unción” del Espíritu Santo, como afirma Juan en su 1a Carta, y por lo tanto "no tienen necesidad que nadie les enseñe, pues su unción, que es verdadera e infalible, les instruirá acerca de todo" (1Jn 2,27) — atacaba de raíz la función magisterial (docente) de sacerdotes y obispos, dejando en cierto sentido en igualdad de condiciones al clero y al laicado. Las autoridades católicas reaccionaron vivamente en contra, acentuando la diferencia. Por este camino se llegó, en el siglo XIX, a hablar de dos iglesias: una iglesia "docente" — constituida fundamentalmente por el Papa y los demás obispos, ayudados por los sacerdotes- y una iglesia "discente"; es decir, una iglesia que enseña (el clero) y una iglesia que aprende (el laicado).

b) Esta fractura interna de la Iglesia católica la ha empezado a revertir el Concilio Vaticano II. En su Constitución dogmática Lumen Gentium sobre 
la Iglesia, se parte del sacramento del bautismo, que nos da a todos los cristianos, independientemente de si ejercemos o no un ministerio en la comunidad, una misma dignidad, porque nos hace igualmente partícipes de Cristo, que es profeta, rey y sacerdote. Durante la asamblea conciliar hubo una fuerte discusión sobre el orden que deberían tener los diversos capítulos de Lumen Gentium. Finalmente se aprobó poner en primer lugar los capítulos sobre el misterio de la Iglesia y el pueblo de Dios y luego los capítulos sobre los ministerios jerárquicos en la Iglesia. Esta decisión indica que la Iglesia es vista por el Concilio como la comunidad de todos los creyentes; a su servicio están luego los diversos ministerios. Un modelo piramidal —que ponía al Papa en cuanto vicario de Cristo en la cúspide y de él se hacía bajar (a los obispos, y de éstos al clero, y de éstos a los fieles) la vida de la fe- es sustituido por un modelo horizontal circular: todos los creyentes estamos igualmente bajo la influencia del Espíritu de Jesús resucitado, que anima a toda la Iglesia suscitando los carismas; los ministros son ordenados para servir al pueblo de Dios en su conjunto, sin apagar los carismas del laicado.

Este clericalismo interno de la Iglesia católica no es producido sólo por el clero, en cuanto se arroga un indebido monopolio en las cosas de la fe. Ha sido también sostenido por un laicado infantil, que se entrega sin chistar a las decisiones del clero. Una anécdota puede ilustrar lo que quiero decir. Hace algunos años un seminarista de mi comunidad recibió un domingo temprano un llamado telefónico de su abuelo, un profesional y profesor universitario de larga trayectoria, una autoridad reconocida en su especialidad. Llamaba a su nieto para “pedirle permiso” — textualmente_ para no ir a Misa, porque estaba enfermo. No creo que se pueda achacar este infantilismo eclesiástico sólo a la formación recibida. Si esa formación se aceptó y se interiorizó es, probablemente, porque daba también seguridad. Ante el temor del pecado grave y de su consecuencia, la condenación eterna, era más seguro descargar sobre otro — sobre todo si ese otro detentaba un poder sacral — la responsabilidad de ciertas decisiones importantes.

En el fondo, el clericalismo se sustenta sobre una falla en la experiencia de fe del creyente laico. La experiencia de fe fue reprimida en la Iglesia católica en los últimos siglos; aquí también hay razones históricas, comprensibles, por los excesos a los que lleva, una y otra vez, un cristianismo entusiasta. La fe se convirtió en un conjunto de verdades sobrenaturales reveladas que creer (el dogma) y de normas de conducta que observar (la moral y las obligaciones litúrgicas). La salida de este clericalismo supone de ambos lados, clero y laicado, un cambio profundo de actitud. 
c) Un aspecto de este cambio que me parece crucial tiene que ver con la capacidad del laico de reflexionar teológicamente su propia vida, para descubrir en ella la presencia de Dios. Me parece útil partir de una experiencia que se me ha ido acumulando con los años ${ }^{12}$. Se trata de las reuniones con papás y padrinos para preparar el bautismo de sus hijos. En la conversación con ellos queda claro el cariño por sus pequeños vástagos, expresado en forma muy intensa e impactante. Pareciera que ante un ser tan pequeño y desvalido como es un recién nacido, se despierta en nosotros lo mejor de nuestro afecto, brota un fuerte deseo de proteger esa vida nueva. Los papás se olvidan de sí y de sus problemas, porque están enteramente volcados hacia su pequeñito(a). Pero cuando les pregunto: ¿Qué papel juega Dios en esta experiencia?, invariablemente todos responden en la línea moral: es una responsabilidad muy grande que Dios nos confía al regalarnos este hijo (o hija) y tenemos que responderle lo mejor posible. Percibo en esto un déficit teológico: Los papás viven ante sus hijos una experiencia muy intensa y hermosa de amor, pero no saben leerla como experiencia de Dios; no saben dar vuelta su propia experiencia, para verse ellos como hijos de Dios, amados por Él con amor paternal y maternal. Pierden así una oportunidad de crecer en su experiencia del amor de Dios, al no saber leer su propio amor de padres como eco y reflejo del amor que Dios nos tiene a cada uno de nosotros.

Me pregunto si esto no se produce también en el resto de la experiencia cotidiana de los laicos: en su vida de pareja, en su trabajo productivo, en su compromiso social, en su tarea política, en su plasmación artística, etc. ¿Cuánta experiencia de Dios hay allí que se pierde? La pierden los propios implicados y la perdemos todos en la Iglesia. Es posible que esta experiencia de Dios se pierda porque los agentes pastorales no hemos sabido enseñar a los laicos a hacer "teología” de su propia experiencia humana. Quizá porque hemos pensado que la experiencia de Dios se hace sólo o principalmente en la oración, en la tarea cotidiana de construir la comunidad y en la tarea pastoral, que son elementos centrales en la experiencia del clero. Sabemos hacer teología de nuestra experiencia, pero no sabemos ayudar a los laicos a que hagan eso mismo con su propia experiencia laical y sepan descubrir a Dios y conocerlo más a fondo leyendo adecuadamente su propia vida de laicos.

Me parece que la salida es motivar al laicado para que haga teología de su experiencia. Los miembros del clero no podemos hacerla, porque no

\footnotetext{
${ }^{12}$ Lo que sigue está más desarrollado en mi texto "Experiencia Laical de Dios”,
} 2002, pp. 20-21. 
tenemos experiencia directa de paternidad y de maternidad, ni de trabajo en empresas, ni de arte, ni de política, etc. Para que el laicado pueda hacer teología de su experiencia, hay algunas condiciones necesarias; nombro tres. 1) Lo decisivo es que el laico sea adulto en su fe. Mientras el cristiano no tenga una experiencia personal de encuentro con el Señor, una experiencia que le haya transformado su vida, una experiencia que sea la base de toda su existencia, el laico será "cliente” del clero. Además esta experiencia de fe debe estar reflexionada por el laico, de manera que sea suya, y en un nivel de profundidad que sea al menos el mismo en que se da su existencia como persona y como profesional, para que le haga el peso. De otro modo, de nuevo, quedará dependiendo del clero. 2) Hay zonas propiamente laicales de la vida de la fe, donde hasta ahora no ha habido suficiente reflexión ni realizaciones adecuadas, precisamente por la falta de un laicado adulto en su fe. Una es la vida de la sexualidad y la familia. Es un escándalo, me parece, que la moral sexual siga siendo hecha, en su gran mayoría, por célibes. Otra zona es la vida social, económica, política. 3) Finalmente, no habrá laicado adulto si no hay un cambio sustancial en el clero. Tenemos que dejar espacio para que el laico sea. Tenemos que devolverle los espacios que le corresponden, también en la vida interna de la Iglesia. Llevamos muchos siglos de clericalismo. Hemos convertido a la Iglesia en una especie de supermercado, donde los laicos son clientes, pero no dueños. Tenemos hermosos textos sobre la Iglesia como comunión de iguales por el bautismo (toda la eclesiología que preparó y luego ha comentado el Concilio); pero nuestra práctica está aún muy lejos de los textos.

\section{Una condición en la relación de la Iglesia con el mundo: Actitud empática}

a) Si miramos ahora la relación de la Iglesia con el mundo, su actitud pastoral debería ser de empatía. Me parece una condición indispensable para lograr la inculturación de la fe en la cultura actual. Desgraciadamente, creo ver en amplios sectores del clero (y del laicado) una actitud más bien autocentrada, que busca hacer de los receptores de la acción pastoral de la Iglesia "prosélitos", es decir, intenta que los receptores simplemente reproduzcan la fe tal como la viven los pastores. En cambio, la actitud empática intenta que el destinatario de la acción pastoral descubra, desde su propio ser y su propia circunstancia, la persona de Jesús y viva su Evangelio de manera inculturada. Me detengo en cuatro aspectos de la acción pastoral. 
Dado que la acción pastoral es fundamentalmente una comunicación del Evangelio de Jesús, el punto decisivo es la capacidad del agente para ponerse en el lugar del receptor. Si la tiene y en alto grado, su actitud será fundamentalmente empática; si no la tiene, su actitud será inevitablemente autocentrada y, por lo tanto, enjuiciadora, porque percibirá las expresiones del destinatario no tal como él es y se expresa sino tal como el agente lo reconstruye desde sí mismo. Un ejemplo puede ilustrar lo que intento decir. Una religiosa trabajó durante un año con un grupo de muchachos campesinos de unos 18 años de edad, que se preparaban para recibir el sacramento de la confirmación. Al finalizar el año quiso ver cuánto habían comprendido del Evangelio. Conversando con uno, le preguntó: “¿Qué es más pecado, matar a un ser humano o a un pajarito?”. Sin vacilar, el joven contestó: “Un pajarito”. En ese momento, según cuenta la religiosa, sintió que su trabajo de un año había sido inútil. Quiso enfurecerse con el muchacho y retarlo despiadadamente. Gracias a Dios, le brotó la pregunta salvadora y tan simple: “¿Por qué?” Y el muchacho, con la misma seguridad con que había respondido a la primera pregunta, contestó: "Porque un cristiano ${ }^{13}$ puede defenderse, pero un pajarito no". (Se puede ver que el joven, además, entendió que se le preguntaba no acerca de un hecho ya realizado - el haber dado muerte- sino acerca de una acción humana, que es siempre un intento de realizar algo.) En su horizonte, muy "primitivo”, el muchacho había captado algo que es parte esencial del Evangelio. Trasladado al horizonte, más "evolucionado", de cualquiera de nosotros, la expresión del joven es aberrante. Pero se trata justamente de empatía y no de enjuiciamiento, porque lo que interesa a la Iglesia — cuando es fiel a lo que le interesa a Jesús - es que cada destinatario del Evangelio entre, tal como es - sin sacarlo de su mundo, sin obligarlo a pasar por el nuestro-, en contacto con Él, que es el Evangelio vivo. El que desde su autocentración enjuicia al otro no necesita preguntar porqués, le basta con percibir y juzgar según sus criterios. El que tiene empatía, en cambio, nunca termina de preguntar, porque nunca se siente totalmente metido en el "pellejo" del otro; para irse metiendo, se acerca al otro, lo acompaña.

b) El agente pastoral autocentrado tiene como objetivo central y prácticamente único imponer al receptor el sistema eclesiástico (doctrinal, moral, litúrgico, devocional y disciplinal) en que ha cristalizado la vida cristiana del agente y que se supone tiene como efecto final la salvación eterna

\footnotetext{
${ }^{13}$ El campesino chileno usa la expresión "un cristiano" como equivalente de "persona".
} 
de los que lo aceptan. No se trata, entonces, de poner al receptor en contacto con Dios y con su voluntad viva, sino de integrarlo al sistema eclesiástico, en el entendido de que ahí se encuentra a Dios y su voluntad. El riesgo que se corre es el de sacralizar el sistema eclesiástico tal como es vivido e interpretado por el agente, atribuyéndolo íntegramente a Dios —olvidando la parte que en su estructuración juega la cultura del agente—, haciéndolo así intocable; con esto, se convierte de hecho en un sistema autónomo, administrado por el agente; en un sistema que pierde su referencia viva a Dios. Por eso, la acción pastoral autocentrada tiende inevitablemente al proselitismo, es decir, a ganar adeptos para la institución eclesiástica. Una consecuencia de esta actitud es que el agente autocentrado tiende a confundir al hombre moderno no cristiano con un mal cristiano; entonces, en vez de ofrecerle el Evangelio, para que se convierta, lo amonesta severamente y con dureza, para que vuelva al buen camino.

El agente pastoral empático, en cambio, quiere ayudar al receptor a que se encuentre personalmente con la voluntad viva de Dios, la acepte y deje que su vida sea conducida por el Espíritu de Dios. No se desconoce la necesidad de un sistema doctrinal, litúrgico, moral, espiritual y disciplinario, pero se lo relativiza doblemente, en el sentido que se lo ve como relativo a Dios y a su voluntad, y se sabe que esta voluntad debe ser aprehendida por el receptor y puesta en práctica en el contexto, siempre particular, de su cultura, que no necesariamente coincide con la del agente. Por eso, la acción pastoral en actitud empática nunca será proselitista —el proselitismo tiende a hacer del receptor una suerte de "clon" del agente— sino auténticamente misionera; porque se tiene clara conciencia de que el agente y su sistema de vida cristiana y de institución eclesial son sólo puente para que Dios y el receptor se encuentren y para que de ese encuentro surja un nuevo sistema, adecuado a la cultura del receptor.

c) De hecho, la acción pastoral de la Iglesia no se da en un espacio vacío y aséptico, sino que se inserta en el campo de las fuerzas que están activas en la sociedad y la cultura. Quiero subrayar dos aspectos fundamentales en esta relación, la que se da con el poder político y con la cultura. En cuanto al poder, el agente pastoral autocentrado tiende a poner como ideal el régimen de cristiandad, que se basa en una alianza de la Iglesia - concretamente, de sus autoridades jerárquicas - con los que detentan el poder en la sociedad. ¿Qué espera el clero de esta alianza? Libertad para realizar su tarea; prestigio para sus funcionarios, por el respeto que deben mostrarles las autoridades públicas; medios económicos y técnicos para poner al servicio de la evangelización. Pero quizá, sobre todo, espera 
tener influencia en la sociedad para poder, al menos, mantenerla libre de influjos perniciosos. De ahí el esfuerzo por controlar la legislación civil, para que no haya ley de divorcio; los programas educacionales, para que no se basen en antropologías no cristianas; los medios de comunicación, para que no difundan pornografía; los espectáculos juveniles, para que no incentiven al consumo de drogas ni a la violencia; etc. En los tiempos actuales estas alianzas no necesitan estar estatuidas en leyes; pueden ser perfectamente tácitas. Porque a los gobiernos también les conviene: reciben legitimación de parte de la Iglesia.

El agente empático, en cambio, prefiere relaciones de mutua libertad con el poder, porque sabe que, en último término, el poder de Dios se revela en plenitud como puro amor y entrega de sí; sabe que Dios — extremando la expresión — no tiene otro poder que su amor. Es lo que se ha manifestado no sólo en la cruz de Jesús — que, desde la perspectiva humana, es el extremo del no-poder — ${ }^{14}$, sino también en la opción de Dios por los pobres a lo largo de toda la historia de la revelación. En la cruz de Jesús y en la opción por los pobres tiene el agente empático los principios fundamentales para ofrecer un servicio crítico al poder. El agente empático busca también que al interior de la comunidad eclesial el poder sea vivido como servicio que da vida; en fidelidad a la eucaristía, en la que el poder que tiene el celebrante de consagrar el pan y el vino está enteramente orientado a que la comunidad pueda alimentar su vida de fe con el sacramento de la entrega total de Cristo. El agente empático piensa que el cristiano — educado en la comunidad eclesial a ejercer el poder como servicio, particularmente en beneficio de los pobres y sufrientes- podrá intentar ejercerlo así también en la sociedad; aquí, cree, puede estar el mejor servicio político de la Iglesia.

d) Con la cultura, el agente pastoral autocentrado tiende a establecer una relación que se va a uno de dos extremos: sea a la disyuntiva tajante entre la fe (obra de Dios) y la cultura (obra humana), sea a la identificación entre la cultura del pueblo o de la nación y la Iglesia, concebida como la depositaria de la identidad cultural del pueblo o la nación. Obviamente, la relación de oposición radical se da sobre todo cuando la Iglesia se siente minoría en una sociedad cuya cultura es contraria o al menos indiferente al Evangelio; y la de identificación, cuando la cultura ha sido ya cristianizada en alguna medida y en ella goza la Iglesia de prestigio. En ambos casos, sin embargo, se trata de imponer una determinada cultura al pueblo.

${ }^{14}$ Véase Noemi, Juan: “Iglesia y Democracia”, 1991, pp. 425-431, sobre todo la reflexión final acerca del verdadero poder de Jesús, pp. 429-431. 
El agente empático entiende que la relación de la Iglesia con la cultura es de discernimiento crítico, en ambas direcciones. En una, la fe aporta elementos para una crítica constructiva de la cultura, a partir de los criterios del Evangelio. Estos criterios la Iglesia tiene que estar continuamente retomándolos, en sucesivas y nunca acabadas aproximaciones al Evangelio, desde la inevitable particularidad de cada horizonte hermenéutico. No están nunca plena y definitivamente poseídos en una formulación inalterable. Una función específica de estos criterios es permitirle a la Iglesia reconocer en las diversas culturas las semillas del Logos y en las diversas situaciones históricas la acción del Espíritu de Dios (los signos de los tiempos). Gracias a este discernimiento, el agente puede acercarse positivamente a la cultura del destinatario, con una sensibilidad abierta y acogedora. La fuente última de este aporte de la fe a la cultura se sitúa en la conciencia de la reserva escatológica que pesa sobre la historia humana, que hace que nada pueda ser aquí todavía plenamente el Reinado de Dios, por lo que la Iglesia ha de ser peregrina en el sentido de no poder instalarse definitivamente en ninguna cultura, por cristiana que parezca o evangelizada que esté. En la otra dirección — crítica de la cultura a la Iglesia—, el agente empático sabe que las culturas también aportan elementos válidos para una crítica constructiva de la vida de la Iglesia y los cristianos que, por el pecado aún no definitivamente vencido, empañan el rostro de Jesucristo en su cuerpo que es la Iglesia en la historia.

En la actitud empática pesa también el respeto por los procesos de las personas, de las instituciones sociales y de la cultura; de modo que más que proponer un modelo ideal de cultura — un proyecto ya hecho, que sólo se trataría de llevar a cabo poniendo los medios adecuados-, se trata de ofrecer fermentos para una vida cultural nueva.

\section{Un núcleo decisivo de la modernidad: La tecnociencia}

a) Cuando se trata de inculturar el Evangelio en una determinada cultura, es imprescindible que los evangelizadores tengan claridad respecto de los núcleos centrales que configuran esa cultura. De otro modo, se corre el riesgo de estar tratando de llevar el Evangelio a zonas periféricas, ornamentales, de la cultura. En ese caso, se estaría dando un mero "barniz superficial”, como advertía Pablo VI ${ }^{15}$.

${ }^{15}$ Evangelii Nuntiandi 20, citado más arriba. 
La cultura es un sistema complejo. Inspirados en un estudio de Jean Ladrière $^{16}$, podemos decir que hay en el sistema cultural cuatro subsistemas. El más exterior es el sistema de expresión. Está constituido fundamentalmente por el lenguaje, pero también por los gestos corporales y los símbolos colectivos. Íntimamente unido a la expresión está el sistema de la acción, que gobierna la forma como se actúa en cada grupo cultural en respuesta a los desafíos que enfrenta el ser humano, desde la subsistencia y la convivencia hasta la búsqueda de sentido. Más adentro en la cultura está el sistema de las representaciones, es decir, de las formas como el grupo se representa las realidades diversas con las que entra en contacto. Es el mundo de las ideas, los mitos, la ciencia, la filosofía, las ideologías, las cosmovisiones. La acción está fuertemente condicionada por las representaciones. Por último, en el centro de la cultura están los valores. Se pueden distinguir dos tipos distintos. Por un lado, los valores axiológicos, que expresan la dignidad de cada cosa, de cada ser, y están, por lo tanto, íntimamente vinculados con las respectivas representaciones, determinándolas. Por otro lado, los valores normativos, que dictan el tipo de conducta que el ser humano debe tener con las diversas cosas del mundo; por eso, se vinculan con el sistema de acción y lo determinan.

Los valores son, pues, el núcleo que determina el conjunto de la cultura, hasta sus niveles más exteriores de expresión y de acción. Hoy se suele hablar, a este propósito, del "ethos" cultural como el centro de la cultura, aquel que determina las actitudes de fondo que gobiernan la conducta del hombre en el mundo. Se lo puede definir como el núcleo en torno al cual se organizan y adquieren coherencia los valores, que constituyen el corazón de la cultura, en cuanto ésta es matriz de la conducta humana y, por lo tanto, del ser humano que se va haciendo a sí mismo por medio de su conducta. Habría que añadir también el "pathos" de la cultura, es decir, la forma fundamental de la sensibilidad, que define el modo como los miembros de un grupo cultural reciben el mundo. Así, la cultura se puede representar por una elipse cuyos dos focos son el "ethos" cultural y su respectivo "pathos". Es a este doble foco al que debe llegar el Evangelio para inculturarse efectivamente en la cultura. Por lo tanto, la pregunta decisiva es: ¿Cuál es el centro — el ethos y el pathos— de la cultura moderna?

b) Aunque es muy difícil ver con claridad lo que está ocurriendo en el presente que nos toca vivir, parece haber consenso en que el mundo hoy

${ }^{16}$ Ladrière, oc., Jean: El Reto de la Racionalidad: La Ciencia y la Tecnología frente a las Culturas, 1978 (Les Enjeux de la Rationalité: Le Défi de la Science et de la Technologie aux Cultures, 1977). 
está sometido a un proceso de globalización, que no es otra cosa que la difusión al mundo entero de la cultura de los países "desarrollados" del hemisferio norte. Otra forma de decir lo mismo es que Chile (al igual que los demás países “en desarrollo”) está en un proceso de modernización. En efecto, la globalización hace universal la cultura moderna del Norte. Cuando hoy se habla de "posmodernidad", se alude a los rasgos propios de la fase actual de la modernidad, que otros prefieren llamar "modernidad tardía", pero que no sería propiamente una cultura nueva con respecto a la modernidad.

Sea de ello lo que fuere, tanto en la modernidad clásica como en la actual fase posmoderna de globalización, un papel clave lo juega la tecnociencia, es decir, la técnica de base científica (llamada hoy habitualmente “tecnología”). Es la tecnociencia la que ha hecho posible la globalización, impensable sin los actuales medios de comunicación y de transporte. Es más, al menos en un primer momento, la globalización consiste en la difusión planetaria de la tecnociencia, que ha ido "colonizando" — para emplear la expresión de Habermas - poco a poco todos los ámbitos de la vida humana, no sólo en sus dimensiones colectivas —la producción y distribución de los bienes, la organización de los procesos sociales, los medios de comunicación y transporte- sino, cada vez más, también en las dimensiones individuales: pensemos en la medicina, la sicología, la educación, en vías de rápida tecnificación gracias al desarrollo de las ciencias humanas y biológicas.

La “colonización” tecnocientífica de la cultura moderna en su fase actual no se verifica sólo en el nivel de los productos y procesos tecnocientíficos que invaden nuestra vida cotidiana. Se da, sobre todo y decisivamente, en el nivel de los valores. Por un efecto de "inducción práctica" — definida por Ladrière como "un fenómeno de trasvase que hace pasar ciertos esquemas de actitudes o de comportamientos desde un dominio en que se ejercen solamente a otro en que son propuestos temáticamente como normas"17-, los valores tecnocientíficos se presentan como los $\checkmark$ valores supremos a los que debe aspirarse. Estos valores consisten fundamentalmente en la objetividad propia de la ciencia moderna y en la eficacia de la técnica de base científica. Desde la acerada crítica de Popper a la pretensión de lograr la verdad por medio de la ciencia moderna - en la que mostró fehacientemente que la experimentación científica no puede comprobar la validez de las hipótesis científicas sino sólo, cuando el experimento

${ }^{17}$ Ladrière, oc., Jean: El Reto de la Racionalidad: La Ciencia y la Tecnología frente a las Culturas, 1978, p. 109. 
contradice la hipótesis, falsificarla (mostrarla falsa) ${ }^{18}$ —, se ha difundido en los círculos filosóficos y científicos un cierto escepticismo, que adopta diversas formas, entre ellas la del pensamiento débil de Gianni Vattimo ${ }^{19}$. En la medida en que las ideas de los pensadores van alcanzando difusión más masiva, se van convirtiendo en actitudes culturales. Hoy me parece constatar que esta crítica de Popper está cristalizando en una actitud que podemos denominar "tecnopositivismo", en que las ideas se validan por su capacidad de generar técnicas que funcionan. El raciocinio parece ser el siguiente: aunque las hipótesis científicas que han superado los intentos de falsificarlas no se puedan declarar verdaderas, sigue siendo verdad que de ellas se pueden obtener aplicaciones técnicas que funcionan, y eso basta. Así, más que la objetividad de la ciencia, se nos va imponiendo como valor la eficacia del mero funcionamiento. Esto podría explicar desde la facilidad con que los estudiantes — secundarios y universitarios- copian en sus pruebas, porque de hecho funciona, y ¡cómo va a ser malo algo que funciona bien!, hasta los grandes escándalos financieros y de violación a los derechos humanos que una y otra vez van saliendo a luz, perpetrados por poderosos y potentados.

c) Un problema serio es que la reflexión sobre la tecnociencia y sus consecuencias no se ha desarrollado con la misma intensidad que la tecnociencia. Por un lado, hasta bien entrado el siglo XX el clima cultural en las sociedades modernas fue decididamente progresista: se esperaba del desarrollo tecnocientífico el progreso continuo de las condiciones de vida de la humanidad. Por otro lado, los filósofos y científicos sociales no se han ocupado mayormente del fenómeno tecnocientífico, quizá por el lastre teórico de la filosofía occidental, que tiende a menospreciar los procesos materiales que, en Grecia, cuna de la filosofía, estaban en manos de esclavos. Recién en 1877 se publica una primera Filosofía de la Técnica ${ }^{20}$, y hay que esperar hasta 1975-1977 para que surja en los EE.UU. la primera Sociedad para la Filosofía de la Técnica (que publica, desde 1978, un anuario: Research

\footnotetext{
${ }^{18}$ Popper, Karl: Logik der Forschung, 1934. (Traducción al inglés: The Logic of Scientific Discovery, 1958; traducción al castellano: La Lógica de la Investigación Científica, 1962.)

${ }^{19}$ Por ejemplo, Vattimo, Gianni y Pier Aldo Rovatti (eds), Il Pensiero Debole, (1983) 1990, pp. 12-28 (trad. cast. de Luis de Santiago: El Pensamiento Débil, Madrid: Cátedra, 1983). Vattimo, Gianni: La Fine della Modernità, (1985) 1987 (trad. cast. de Alberto L. Bixio: El Fin de la Modernidad: Nihilismo y Hermenéutica en la Cultura Posmoderna, Barcelona: Gedisa, 1986).

${ }^{20}$ Kapp, Ernst: Grundlinien einer Philosophie der Technik. Zur Entstehungsgeschichte der Cultur aus neuen Gesichtspunkten, 1978 (1877).
} 
in Philosophy and Technology). Si la reflexión se ha demorado en los países del Norte, que han sido la cuna de la tecnociencia, no es de extrañar que en los países de América Latina esté aun más en sus inicios. A esto se añade la influencia que ha tenido el triunfal desarrollo de la tecnociencia sobre la misma filosofía. Hacia mediados del siglo XIX esa influencia cristalizó en el primer movimiento positivista, liderado por Auguste Comte, que ha tenido luego una larga serie de reviviscencias, entre las cuales ha sido muy influyente el Neopositivismo (o Positivismo Lógico) del Círculo de Viena, cuyo Manifiesto se publicó en 1929. En los diversos positivismos se parte de una misma base: el conocimiento por excelencia, el que ejerce las capacidades de la razón en forma óptima, es el conocimiento científico experimental, es decir, el que da origen a la tecnociencia. Si la ciencia es el modelo del ejercicio correcto de la razón, ¿cómo someterla a crítica racional? Se puede señalar también la influencia que ejerce la creciente difusión de los objetos y los procesos tecnocientíficos sobre las maneras de ver y de pensar, de sentir e imaginar el mundo de todos los que viven en sociedades modernas o en proceso de modernización. Como ha señalado Ramón Queraltó, el ser humano que vive hoy en una sociedad moderna ya no es, como afirmaba Heidegger, un "ser-en-el-mundo" sino, de hecho, un "ser-en-latécnica"21. Con consecuencias antropológicas que están lejos de haber sido aclaradas.

Hay, pues, un desequilibrio entre el enorme desarrollo tecnocientífico actual y la aún escasa reflexión sobre él. Si no hacemos esfuerzos por revertirlo, se corre el riesgo de creer —o, al menos, de actuar como si creyéramos - que la tecnociencia es un proceso natural, tan inevitable como la rotación de la Tierra. Esta "naturalización” del fenómeno tecnocientífico oculta su carácter histórico, es decir, desconoce que es fruto de decisiones humanas libres, lo que hace posible que se lo utilice como herramienta de opresión de personas y pueblos. En el caso de Chile, esta reflexión se hace más urgente, debido al amplio consenso en que tenemos que modernizarnos y que eso se logra asumiendo sin más la tecnociencia de los países del Norte.

d) La teología cristiana no se ha hecho cargo aún del fenómeno tecnocientífico de manera adecuada, a pesar de que muchos de los impulsos y de las motivaciones en su desarrollo histórico han sido de origen bíblico y cristiano, como han mostrado, desde perspectivas muy disímiles Stöc-

${ }^{21}$ Queraltó, Ramón: "Racionalización Tecnológica y Mundo Futuro: La Herencia de la Razón Moderna”, 1998, pp. 203-219, la cita en p. 203. 
klein $^{22}$, White ${ }^{23}$ y Noble ${ }^{24}$. Hay aquí, entonces, un nuevo desequilibrio, esta vez entre el interés que los teólogos deberían prestar al fenómeno tecnocientífico y el que efectivamente le prestan. Es probable que esta falta de atención de la teología a la tecnociencia se haya debido al hecho de que las Iglesias cristianas europeas — particularmente la Iglesia católica, como hemos recordado- se pusieron muy luego en contra de la incipiente modernidad; y ésta —en buena medida como reacción ante las guerras de religión que asolaron Europa al producirse la Reforma protestante y que recién se aplacaron con la Paz de Westfalia en 1648- hizo lo posible por exiliar la religión del escenario social y político, relegándola al ámbito de la subjetividad privada. El hecho es que recién hacia 1940 aparecen los primeros escritos de teólogos que intentan — como Gustave Thils- hacer una "teología de las realidades terrenas"25, entre las cuales la técnica y la ciencia ocupan un lugar. Ya antes había habido alguna preocupación por el fenómeno técnico, como se ve por el libro de Hanns Lilje —un pastor protestante, encargado de la pastoral en una Universidad técnica- Das technische Zeitalter. Versuch einer biblischen Deutung (La Era Técnica. Ensayo de una Interpretación Bíblica) de 1928. Pero los escritos anteriores son de carácter más pastoral que teológico propiamente tal; habitualmente se trata de la publicación de charlas dadas por algún teólogo en encuentros pastorales que convocan a ingenieros cristianos y a otros profesionales de las disciplinas tecnocientíficas. A esto se añade el carácter fragmentario y disperso de la producción teológica sobre la tecnociencia, causado por el hecho de que cada teólogo que toma la palabra sobre el fenómeno técnico lo hace como partiendo desde cero, sin conocer —al menos, sin citar- los trabajos anteriores, normalmente publicados en boletines pastorales o revistas de divulgación de alcance muy restringido, casi nunca en las revistas donde se hace la ciencia teológica. Finalmente, en los currículos de las Facultades de Teología el tema de la tecnociencia no está integrado en ninguna de las disciplinas teológicas tradicionales, lo que hace que su tratamiento sea libre, dependiendo de los intereses de los profesores; de hecho, prácticamente no es tratado nunca. Este rasgo de fragmentariedad, dispersión y ausencia de los lugares donde se hace la teología científica, que he

\footnotetext{
22 Stöcklein, Ansgar Anton: Leitbilder der Technik. Biblische Tradition und technischer Fortschritt (1550-1750), 1969.

${ }^{23}$ White Jr., Lynn: “The Historical Roots of the Ecologic Crisis”, 1972, pp. 259-265. (Originalmente publicado en Science, 1967).

${ }^{24}$ Noble, David F.: The Religion of Technology. The Divinity of Man and the Spirit of Invention, 1997.

${ }^{25}$ Thils, Gustave: Théologie des Réalités Terrestres, I: Préludes, 1946.
} 
señalado en las reflexiones teológicas sobre la tecnociencia, explica que no haya habido el necesario debate crítico entre los teólogos sobre el fenómeno tecnocientífico.

Para la teología cristiana, sin embargo, la atención al fenómeno tecnocientífico no es algo secundario ni menos aun prescindible, sino que se inscribe al interior de su tarea de hacerse cargo de la realidad histórica del ser humano y su cultura, para hacerse en verdad contemporánea de sus destinatarios. La teología, en efecto, en su relación con la cultura de cada época debe ser dialogal y comunicativa. La teología cristiana parte de la fe en que en Jesús de Nazaret Dios ha dado a la humanidad una clave que ilumina la existencia; la tarea de la teología es hacer ver, en cada generación, en cada cultura y en cada lugar, que los interrogantes que ahí se formulan pueden encontrar en la vida, el mensaje y la persona de Jesús una luz nueva, que permite abordarlos de mejor manera. Para ello, la teología tiene que estar en diálogo atento con las preguntas que surgen en las diversas culturas y con las capacidades y posibilidades humanas que se abren en ellas. Porque sólo puede comunicar aquel que está dispuesto a escuchar honestamente a su interlocutor.

En particular, como la teología es una reflexión sistemática (científica), tiene que estar en diálogo con la forma como en cada cultura se entienden la verdad y el ejercicio de la razón y con las preguntas fundamentales que en ella se plantean. Y tiene que estar dispuesta a encontrar en ellas no sólo lo negativo (el pecado) sino también y sobre todo lo que ya en los primeros siglos del cristianismo se conoció como "semillas del Logos", es decir, presencia de Dios en las culturas, más allá de los grupos y las instituciones creyentes.

Este desequilibrio entre la escasa reflexión teológica sobre la tecnociencia y la importancia y la necesidad de esta reflexión puede llevar no sólo a una cierta intrascendencia de la teología, por no hablar en el lenguaje de su tiempo. Más a fondo, es una falta al propio estatuto de la teología como ciencia y priva a la sociedad y a la cultura de un aporte que ella podría dar para enfrentar mejor los desafíos actuales que plantea la tecnociencia. Este aporte es, a la vez, crítico y creativo. Crítico, porque lo propio de la fe cristiana (y de la teología que reflexiona sobre ella) es su capacidad de discernimiento crítico de las culturas, a la luz del Evangelio de Jesús. El aporte de la teología es también creativo, porque del Evangelio de Jesús surgen unas orientaciones precisas que impulsan a establecer relaciones respetuosas tanto con la naturaleza —amenazada en sus equilibrios ecológicos por una tecnociencia muchas veces irrespetuosa- como entre los 
seres humanos, tantas veces divididos y enfrentados en clases y naciones antagónicas, en que las más fuertes utilizan los frutos de la tecnociencia para oprimir y explotar a las más débiles.

Podemos concluir que sin una transformación de las actitudes del clero tanto en su relación con el laicado como con el mundo y sin un adecuado desarrollo de la reflexión crítica sobre la tecnociencia, tanto en las ciencias sociales y la filosofía como en la teología, la Iglesia católica no podrá enfrentar adecuadamente el desafío de inculturar el Evangelio en la actual fase de la modernidad en que estamos viviendo un proceso de globalización tecnocientífica. Y la sociedad y la cultura actuales se quedarán sin el aporte de vida que proviene del Evangelio de Jesús.

\section{REFERENCIAS}

Concilio Vaticano II: Lumen Gentium (Constitución dogmática sobre la Iglesia), 1964.

Concilio Vaticano II: (GS) Gaudium et Spes (Constitución pastoral sobre la Iglesia), 1965.

Kapp, Ernst: Grundlinien einer Philosophie der Technik. Zur Entstehungsgeschichte der Cultur aus neuen Gesichtspunkten. Düsseldorf: Stern Janssen, 1978 (original de 1877).

Ladrière, oc., Jean: Les Enjeux de la Rationalité: Le Défi de la Science et de la Technologie aux Cultures. Paris: Aubier-Montaigne, 1977. (Analyse et Raisons 24). (Traducción al castellano: El Reto de la Racionalidad: La Ciencia y la Tecnología frente a las Culturas. Salamanca: Sígueme; París: UNESCO, 1978 [Hermeneia 11].)

Lilje, Hanns: Das Technische Zeitalter. Versuch einer biblischen Deutung. Berlin: 1928.

Noble, David F.: The Religion of Technology. The Divinity of Man and the Spirit of Invention. New York: Alfred A. Knopf, 1997.

Noemi, Juan: “Iglesia y Democracia”. En Mensaje, 40 (№ 404, noviembre 1991).

Pablo VI: Evangelii Nuntiandi (Exhortación apostólica), 1975.

Pío IX: Quanta Cura (Encíclica), 1864.

Popper, Karl: Logik der Forschung, 1934. (Traducción al castellano por V. Sánchez de Zavala: La Lógica de la Investigación Científica, Madrid: Tecnos, 1962.)

Queraltó, Ramón: "Racionalización Tecnológica y Mundo Futuro: La Herencia de la Razón Moderna”. En Seminarios de Filosofía, 11, 1998.

Silva ss.cc., Sergio: "Experiencia Laical de Dios”. En Noticias SS.CC., año 41, N 270, septiembre-octubre 2002.

Stöcklein, Ansgar Anton: Leitbilder der Technik. Biblische Tradition und technischer Fortschritt (1550-1750). München: Heinz Moos, 1969.

Thils, Gustave: Théologie des Réalités Terrestres. I: Préludes. Bruges: Desclée de Brouwer, 1946.

Vattimo, Gianni: La Fine della Modernità. Milano: Garzanti, 2a ed. 1987 (1985). (Saggi Blu). (Traducción al castellano por Alberto L. Bixio: El Fin de la Modernidad: Nihilismo y Hermenéutica en la Cultura Posmoderna. Barcelona: Gedisa, 1986.) 
Vattimo, Gianni y Pier Aldo Rovatti (eds): Il Pensiero Debole. Milano, Feltrinelli, $7^{\mathrm{a}}$ ed. 1990 (1983). (Idee). (Traducción al castellano por Luis de Santiago: El Pensamiento Débil. Madrid: Cátedra, 1983.)

White Jr., Lynn: “The Historical Roots of the Ecologic Crisis”. En Carl Mitcham y Robert Mackey (eds), Philosophy and Technology: Readings in the Philosophical Problems of Technology. New York: The Free Press, 1972. (Originalmente publicado en Science, 1967.) 